\title{
SOLUBLE EXPRESSION OF SYNTHETIC CSF3sYn GENE FUSED WITH THIOREDOXIN IN Escherichia coli BL21(DE3) THROUGH AUTOINDUCTION METHOD AND PURIFICATION
}

\author{
Riyona Desvy Pratiwi*, Asrul Muhamad Fuad
}

Research Center for Biotechnology, Indonesian Institute of Sciences JL. Raya Jakarta - Bogor Km.46 Cibinong 16911 Bogor - Indonesia

Submitted: 28-08-2014 Revised: 20-09-2014 Accepted: 05-12-2014

*Corresponding author Riyona Desvy Pratiwi

Email:

riyona_dp@live.com

\begin{abstract}
A synthetic human gene of CSF3 (CSF3syn.EC3), coding for hG-CSF was succesfully subcloned into pET32a(+) expression vector and fused with thioredoxin (Trx) at its N-terminal as fusion partner. The obtained fusion gene of Trx-CSF3syn within the recombinant plasmid pET32a(+)_CSF3yn.EC3 was verified by PCR, plasmid restriction, and DNA sequencing analysis. In order to investigate the fusion gene expression, we transformed Escherichia coli BL21(DE3) as the host with the recombinant plasmid. The gene was succesfully expressed within the cytosol as fusion protein of Trx.tag, His.tag, S.tag, EK-site, and hG-CSF moieties. By the auto induction method, $49 \%$ of the protein was found in the soluble fraction and the other $51 \%$ was found in the insoluble fraction. The soluble fraction was subsequently purified by IMAC method (Ni-NTA) and characterized.
\end{abstract}

Key words : hG-CSF, thioredoxin, autoinduction, IMAC, E.coli.

\section{INTRODUCTION}

Granulocyte colony stimulating factor (G-CSF) or colony stimulating factor 3 (CSF3) is a hematopoietic cytokines that activates and regulates the production of mature neutrophile, acts on cell survival and differentiation (Metcalf, 1987; Nagata, 1986). It has been studied to have indications in post chemotherapy neutropenia, bone marrow transplantation, severe chronic neutropenia, and in hematologic malignancies (Dale, 1998; Welte, 2012).

Human G-CSF (hG-CSF) is $19.5 \mathrm{kDa}$ in molecular weight and O-glycosilated at Thr133 (Souza, 1986 and Welte, 2012). Post translational modification is not an issue for hG-CSF because O-glycosilated bond does not bind with receptor, so both of the wild-type and non-glycosylated mutant recombinant hGCSF possess colony stimulating activities (Wingfield, 1988; Hill, 1993). However, the Oglycosilated bond has an important role to avoid aggregation, thus, hG-CSF is frequently produced in E. coli as inclusion bodies (Yamamoto, 2002; Dasari, 2008).

Thioredoxin (Trx) was used to improve the solubility of various eukaryotic proteins in E. coli (Lavielli, 1993; Yasukawa, 1995; Sandhev, 1998). Therefore, we are fascinated to apply
Trx as a fusion partner to obtain soluble hGCSF in E. coli BL21(DE3) using auto induction method. This method is more practical and less expensive than the conventional IPTG-induced method (Blommel, 2007, and Li, 2011). It is based on the principle of diauxic growth caused by two types of carbon source, i.e glucose and glycerol as the rapidly metabolized carbon sources and lactose as the slowly metabolized carbon source (Studier, 2005).

The aim of this study is to develope a new approach to express soluble hG-CSF by fusing with Trx and investigate autoinduction as an alternative method for this fusion protein expression. Therefore, the larger or even commercial scale of hG-CSF will be more applicable, more effective and efficient.

\section{MATERIAL AND METHODS}

Subcloning of CSF3syn into expression vector pET32a(+) and its transformation into expression host Escherichia coli BL21(DE3)

A synthetic gene coding hG-CSF was amplified by PCR of recombinant plasmid p'TZ57R/T_CSF3syn.Ec using Applied Biosystem 2720 Thermal Cycler (Foster City, USA) (Wulandari, 2010). Restriction sites of $B g / I I$ and stop codons were added by PCR amplification, this gene is subsequently named 
CSF3syn.Ec3. The CSF3syn.Ec3 and pET32a(+) (Novagen, Darmstadt, Germany) were cut with restriction enzyme of $B g l I I$ (Fermentas, Vilnius, Lithuania), then ligated with T4 DNA ligase kit (Fermentas, Vilnius, Lithuania). The ligation product was transformed into a cloning vector E. coli XL1-Blue (Fermentas, St. Leon Rot, Germany) by heat shock method (Sambrook, 2001). The recombinant plasmid was verified by plasmid restriction and DNA sequencing analysis. In order to express the gene, the recombinant plasmid was transformed into E. Coli BL21(DE3) (Novagen, Darmstadt, Germany) as by heat shock method (Sambrook, 2001).

\section{Small scale overexpression of CSF3syn through autoinduced method}

Pre-inoculum was prepared from $50 \mu \mathrm{L}$ glycerol stock of BL21(DE3)_pET32a(+) _CSF3syn.Ec3 in $1 \mathrm{~mL}$ Luria Bertani medium (Sambrook, 2001) and incubated at $37^{\circ} \mathrm{C}$, 150rpm, 18h (Series 2G Incubator Shaker, New Brunswick Scientific, Edison, New Jersey, USA). The pre-inoculum was added into $10 \mathrm{~mL}$ ZYP-5052 autoinduction expression medium (Studier, 2005), then incubated at $20^{\circ} \mathrm{C}, 170 \mathrm{rpm}, 24 \mathrm{~h}$ (Heidolph Unimax 1010 Incubator Orbital Shaker, Germany). The cells were resuspended in lysis buffer contains of $100 \mathrm{mM}$ Tris- $\mathrm{Cl} \mathrm{pH} \mathrm{7.4;3mM} \mathrm{EDTA,} \mathrm{and}$ $2 \mathrm{mM}$ PMSF $(8 \mathrm{~mL} / \mathrm{g}$ wet cells pellet) and then lysed by freezing at $-20^{\circ} \mathrm{C}$ and thawing in water bath at room temperature, app. 30min respectively, for ten cycles. Soluble protein was obtained by centrifugating the lysed cells at $12,000 \mathrm{rpm}$ for $15 \mathrm{~min}, \pm 4^{\circ} \mathrm{C}$ (Heraeus Sepatech Biofuge 13, Germany). Chemical reagents and other components for medium were purchased from Merck, Sigma, Biobasic, and Caisson Labs.

\section{Purification and characterization hG-CSF}

The soluble crude protein was added to Ni-NTA agarose matrix (1:1) (Qiagen, Hilden, Germany), then incubated on a rotator for $18 \mathrm{~h}$ at $4^{\circ} \mathrm{C}$. The slurry was washed using $20 \mathrm{mM}$ and $30 \mathrm{mM}$ imidazole (Biobasic, Markham, Canada), meanwhile the target fusion protein was recovered by elution with $100 \mathrm{mM}$ imidazole in 15 fractions.
The imidazole solution was prepared in $0.16 \mathrm{M}$ Tris. $\mathrm{Cl}$ pH 7.4 buffer enriched with $4 \mathrm{M} \mathrm{NaCl}$. The first to the fourth elution fraction were collected and dialysed in $0.05 \mathrm{M}$ Tris. $\mathrm{Cl} \mathrm{pH} 8.0$ buffer for $24 \mathrm{~h}$ at $4^{\circ} \mathrm{C}$ with three times of buffer changing. The dialyzed protein was cut with enterokinase (EK) (Invitrogen, Carlsbad, USA), 1U enzyme for $100 \mu \mathrm{g}$ fusion protein, then was incubated at $4{ }^{\circ} \mathrm{C}$ and $20^{\circ} \mathrm{C}$ for $16 \mathrm{~h}$, respectively. hG-CSF and 6His-Trx tag were separated with IMAC as well. Both proteins were concentrated using NanoSep ${ }^{\circledR}$ centrifugal filter column (Pall Life Sciences, East Hills, New York, USA) from $300 \mu \mathrm{L}$ to $50 \mu \mathrm{L}$. The proteins were characterized by western blot using mouse anti-His monoclonal primary antibody (GE Healthcare, Buckinghamshire, UK), goat anti-mouse IgG-AP secondary antibody (Santa Cruz Biotech, Santa Cruz, USA), and detected with Stabilized Substrate for Alkaline Phosphatase (Promega, Madison, USA).

\section{RESULTS AND DISCUSSION}

Subcloning of CSF3syn into expression vector $\mathrm{PET} 32 \mathrm{a}(+)$ and its transformation into $E$. coli BL21(DE3)

The target gene was constructed to be expressed as fusion protein of hG-CSF with Trx $\cdot$ tag and $6 \times$ His $\cdot$ tag provided at the backbone of pET32a(+). The enterokinase (EK) site was added at N-terminal of hG-CSF which is functional towards separation of hGCSF and Trx $\cdot \operatorname{tag}$ (Figure 1).

Thirty three transformants of XL1Blue_pET32a(+)_csf3syn.Ec3 were gained, but there were only 14 transformants positively carry the insert of $c s f 3 s y n$.Ec3 (Figure 2.A); three transformants had proper orientation (Figure 2.B), and two recombinant plasmid were succesfully cut with $B g / I I$ (Figure 2.C). Those two transformants were analyzed by DNA sequencing and both of them had the correct DNA sequence (data not shown). To express the target gene, the recombinant plasmid was transfered from E.coli XL1-Blue to E.coli BL21(DE3), resulting 238 transformants. Confirming by colony PCR, five of 20 randomly selected transformants were positively carrying the target gene. (Figure 2.D). 
Riyona Desvy Pratiwi

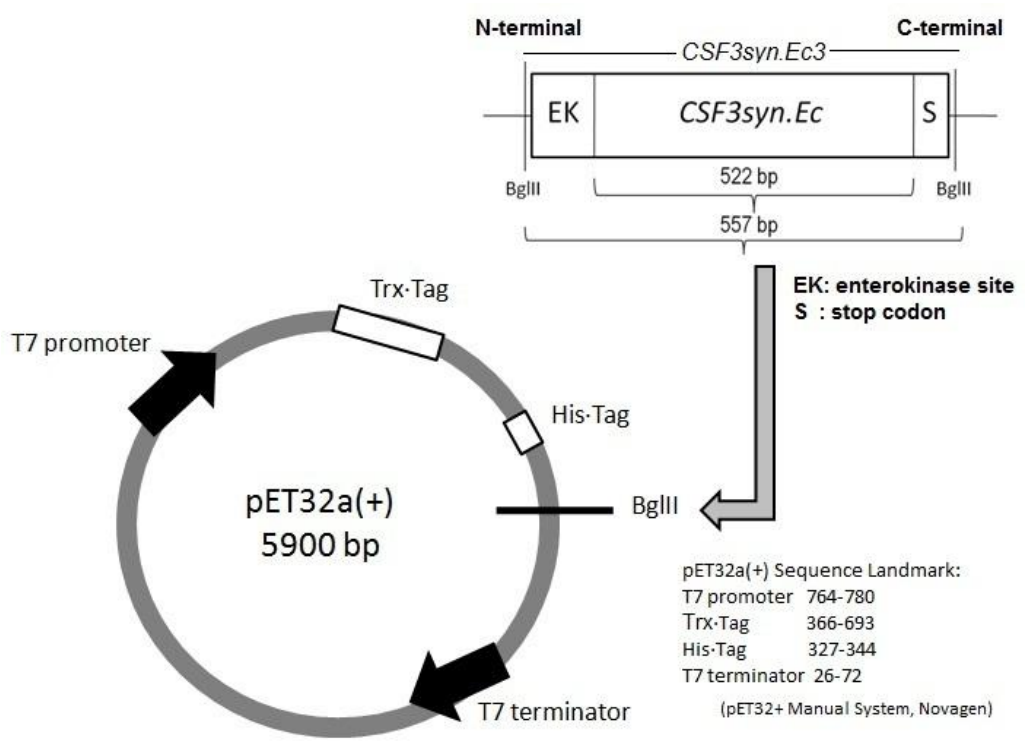

Figure 1. The construction of CSF3syn.Ec3 and pET32a $(+)$

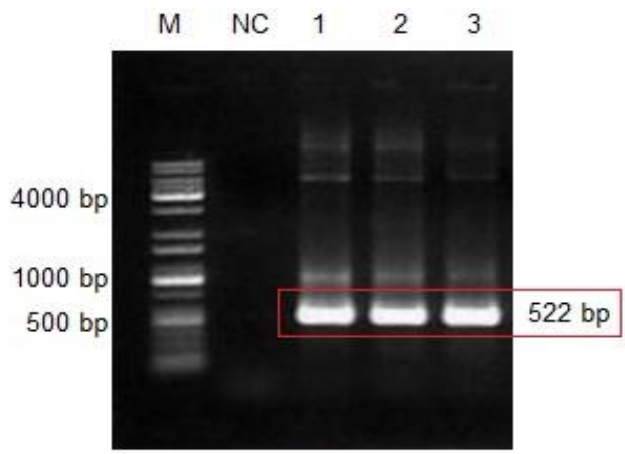

A

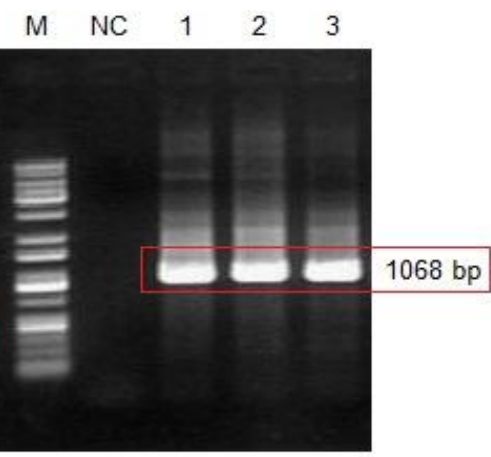

B

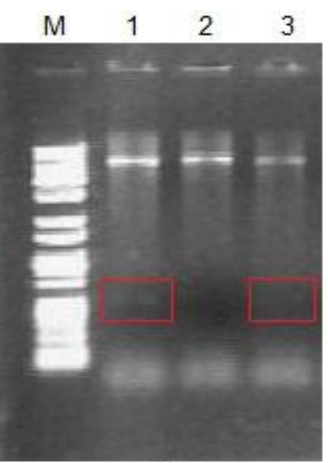

C

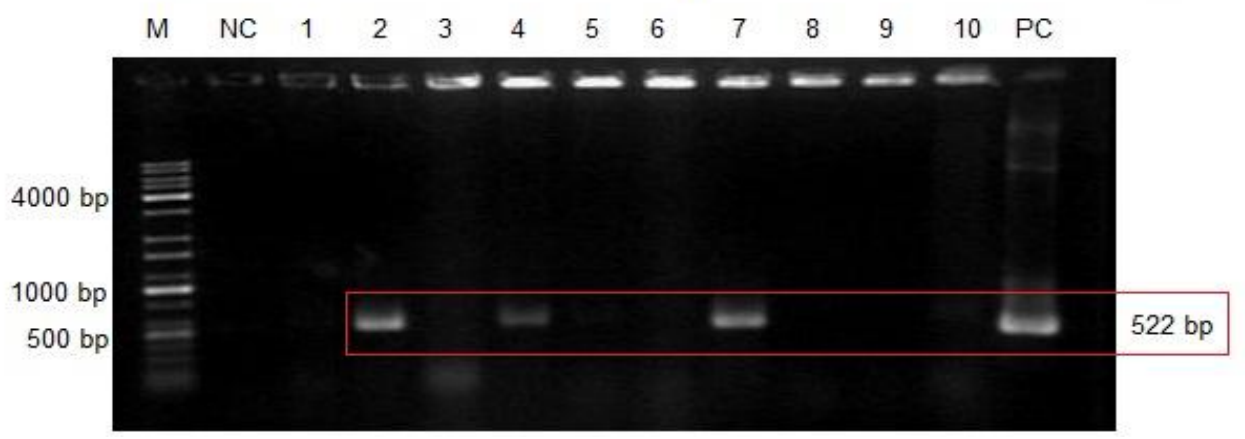

D

Figure 2. DNA Electrophoresis A. PCR product of pET32a $(+)$ _CSF3syn.Ec3 with R-and F- insert gene primers. B. PCR product of pET32a $(+)_{-}$CSF3syn.Ec3 with T7 promoter and R-insert gene primer C. pET32a(+)_CSF3syn.Ec3 cut with BglII, lane 1 and 3 shows CSF3syn.Ec3 as restriction product D. Colony PCR of BL21(DE3)_pET32a(+)_CSF3syn.Ec3 with R- and F- insert gene primers. $\mathrm{M}=1 \mathrm{~kb}$ DNA Marker; $\mathrm{NC}=$ negative control; $\mathrm{PC}=$ positive control or recombinant plasmid pET32a(+)_CSF3syn.Ec3 


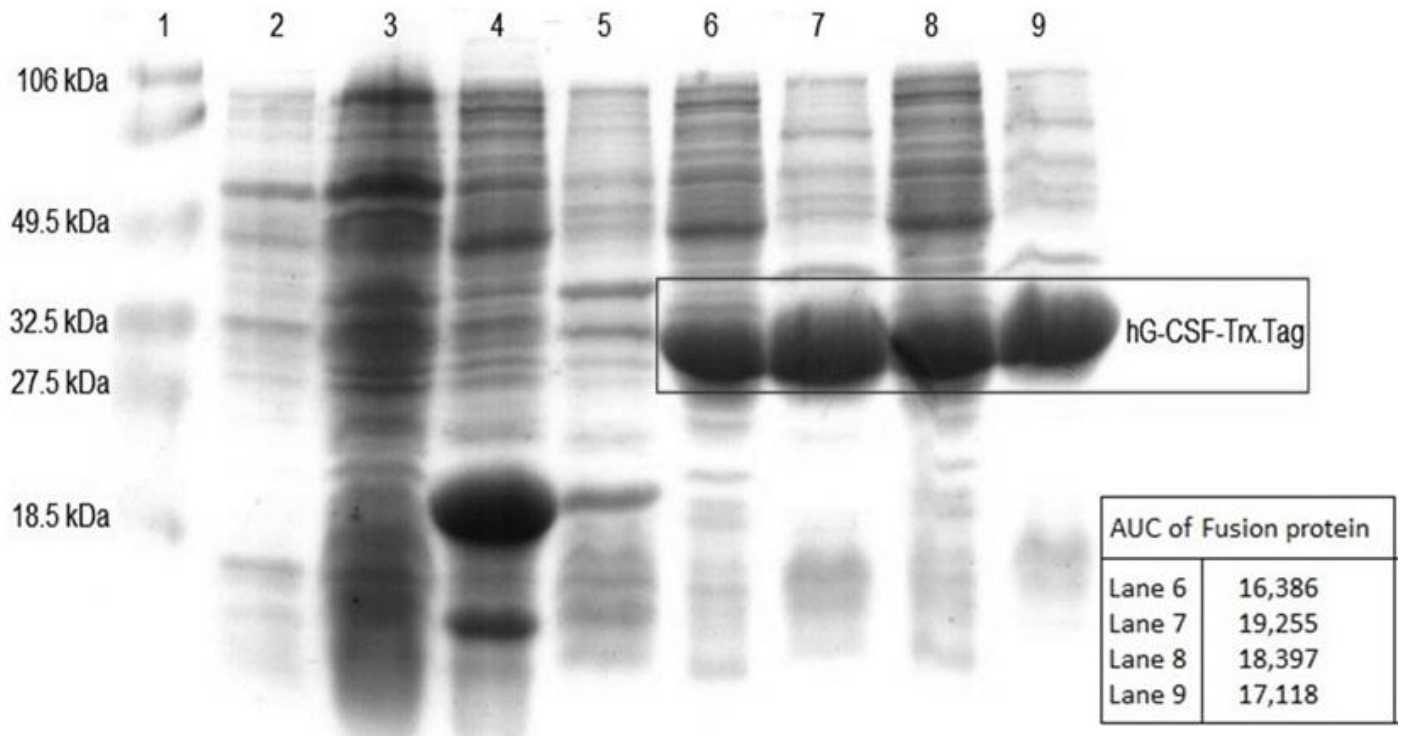

Figure 3. Crude protein profile on 15\% SDS-PAGE

Lane 1) Protein Marker; Lane 2)Non transforman BL21(DE3) soluble protein, Lane 3) Non transforman BL21(DE3) insoluble protein, 4) Transforman without insert gene BL21(DE3)_pET32a(+) soluble protein, Lane 5) Transforman without insert gene BL21(DE3)_pET32a $(+)$ insoluble protein, Lane 6 and 8) Transforman BL21(DE3)_pET32a(+)_CSF3syn.Ec3 soluble protein, 7 and 9) Transforman BL21(DE3)_pET32a(+)_CSF3syn.Ec insoluble protein

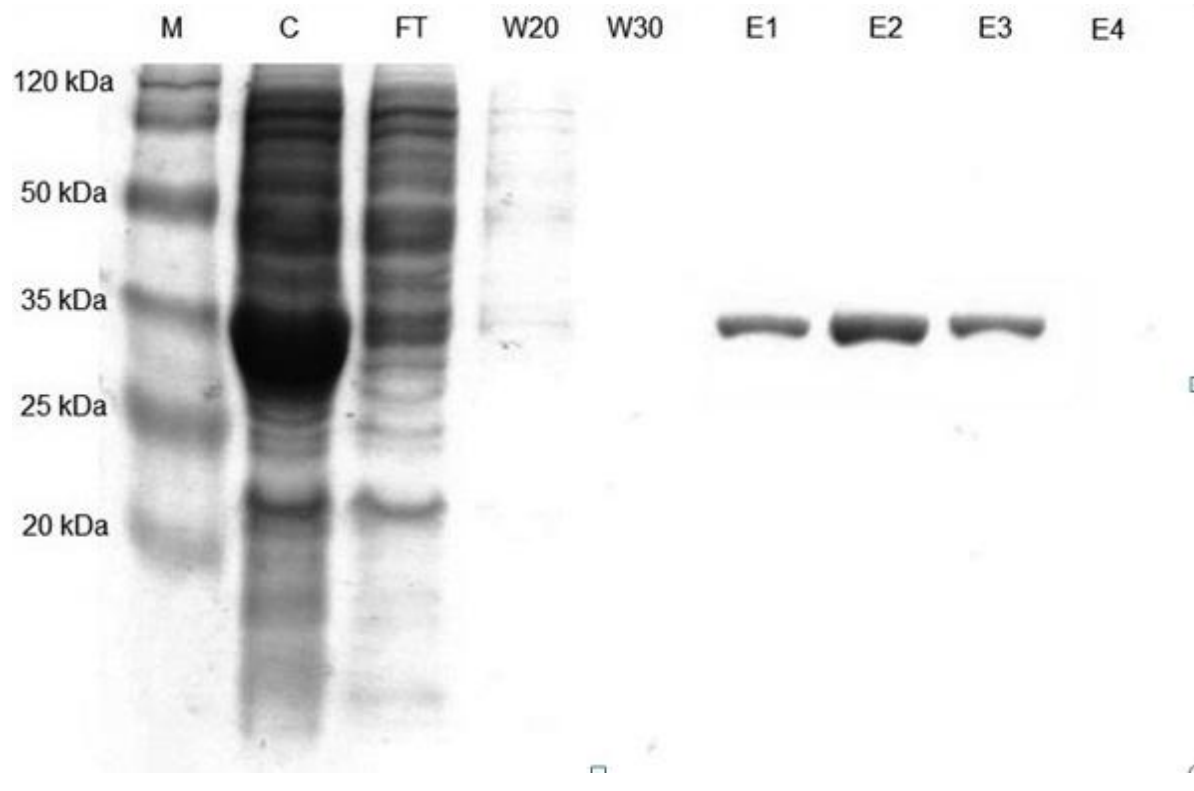

Figure 4. IMAC (Ni-NTA) purified protein profile on 15\% SDS PAGE

M) Protein Marker, C)Crude or unpurified protein, FT) Flow through, protein that not binds to the matrix, W20) Washing fraction with $20 \mathrm{mM}$ imidazole, W30) Washing fraction with $30 \mathrm{mM}$ imidazole, E1-E4) 1st to 4th elution fractions with $100 \mathrm{mM}$ imidazole 


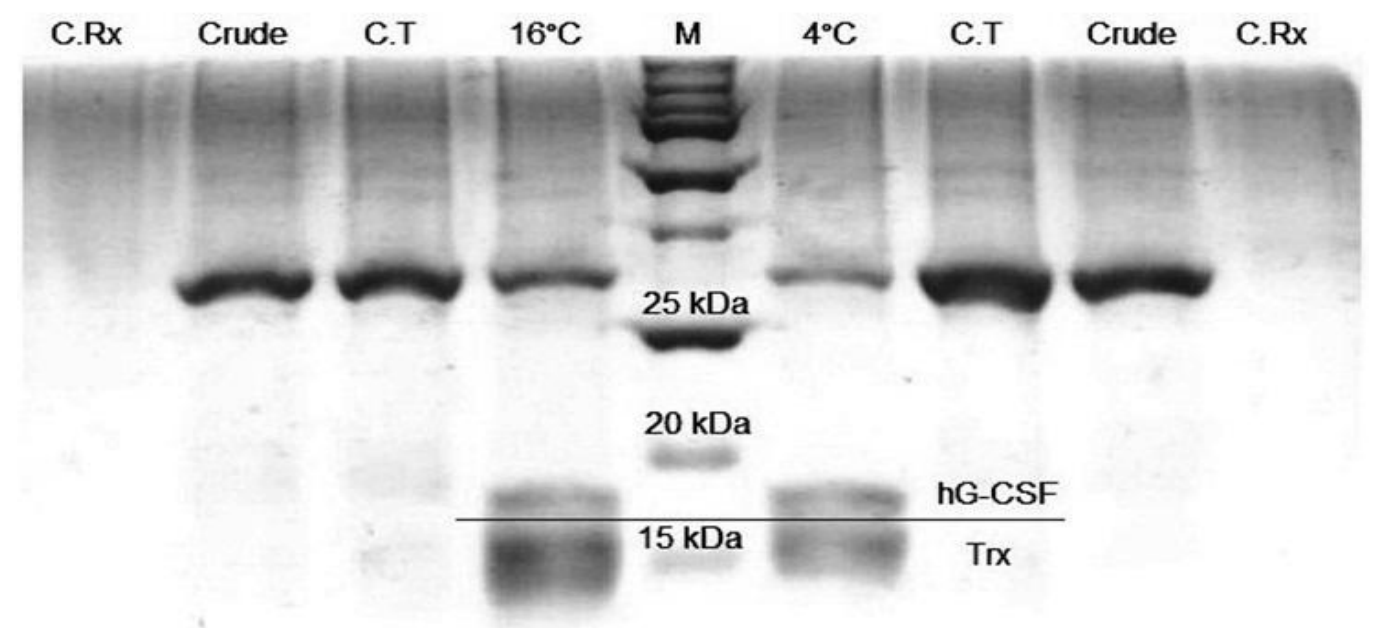

Figure 5. Enterokinase cleaved fusion protein profile on 18\% SDS PAGE

Lane C.Rx) Control of reaction, contains of EK and EK buffer, Lane Crude) Dialysed purified fusion protein, Lane C.T) Control of temperature, contains of dialysed fusion and EK buffer, Lane $16^{\circ} \mathrm{C}$ ) Cleaved fusion protein incubated at $20^{\circ} \mathrm{C}$, Lane $4^{\circ} \mathrm{C}$ ) Cleaved fusion protein incubated at $\left.4^{\circ} \mathrm{C}, \mathrm{M}\right)$ Protein marker

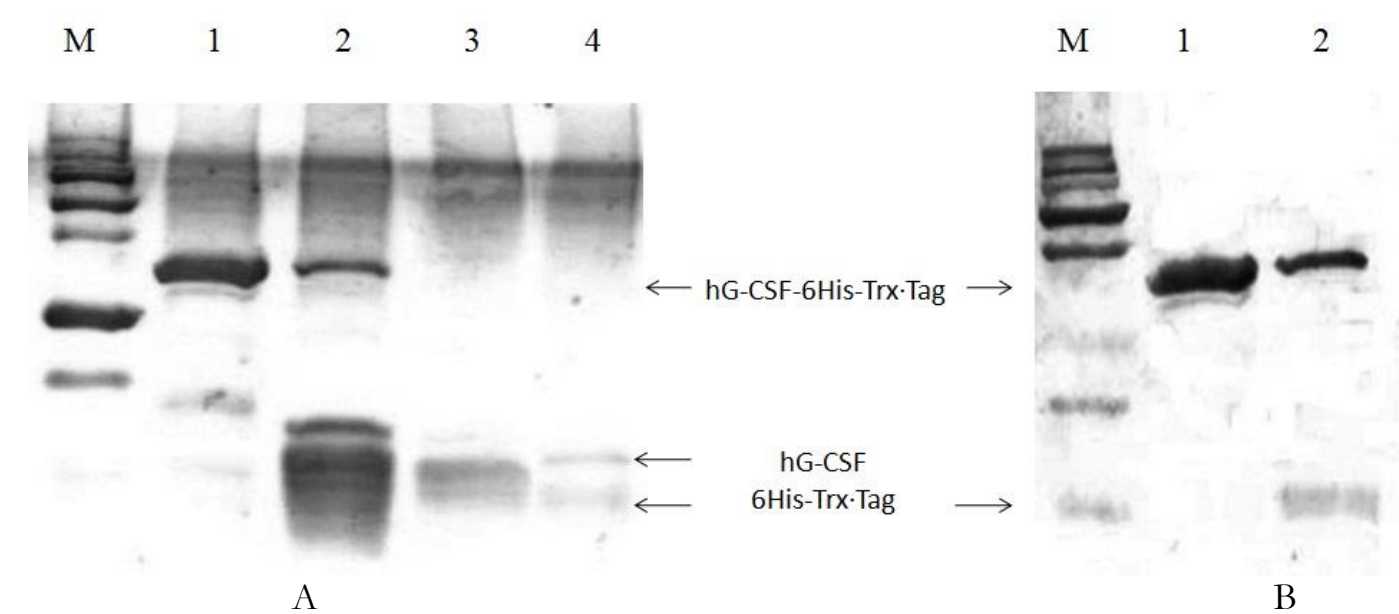

Figure 6 A. The second purified protein profile on 18\% SDS PAGE; Lane M) Protein marker, Lane 1) Trx-hG-CSF fusion protein before EK cleavage, Lane 2) Trx-hG-CSF fusion protein after EK cleavage, Lane 3) Concentrated flow through fraction, Lane 4) Concentrated elution fraction with $100 \mathrm{mM}$ imidazole.Figure 6.B. Western Blot with anti-His primary antibodyLane M) Protein marker, Lane 1) Trx-hG-CSF fusion protein before EK cleavage, Lane 2) Trx-hG-CSF after EK cleavage

\section{Small scale overexpression of CSF3syn through autoinduced method}

hG-CSF is prone to form inclusion bodies (IB) in E.coli because of its hydrophobicity and disulphide bonds (Dehaghani, 2010). This protein has five Cys residues that form two disulphide bonds between Cys37-Cys43 and Cys65-75, and another Cys18 a free Cys residue which is not involved in any disulphide bond formation (Wingfield, 1988). It is complicated to recover soluble protein from IBs related to initial recovery, solubilization, and renaturation steps, hence, fusion partners are commonly considered to obtain the soluble protein (Thatcher, 1990). 
Several fusion partners have been successfully investigated to enhance the solubility of hG-CSF with IPTG induced method, e.g. EDA or E.coli 2keto-3-deoxy-6phosphogluconate aldolase (Kang, 2014) and ArsC or arsenate reductase (Song, 2011). Das (2012) carried out an experiment with Trx 'tag by IPTG induced method to increase the solubility of hGM-CSF, another colony stimulating factor which is useful to maintain post transplantation leukocytes level. In addition, Trx has the ability to be spesifically released from the E.coli cytoplasma by freezethaw methods or osmotic shock in the presence of EDTA, which facilitates to isolate the protein from the cells (LaValielli, 1993).

Two transformants of BL21(DE3) pET32a $(+) \_C S F 3 s y n . E c 3$ were randomly selected and gave the similar profile on $15 \%$ SDS PAGE (Figure 3). In our previous study, the expression level of soluble hG-CSF-Trx ·tag was higher through autoinduction than IPTGinduced method and it was increased by lowering the incubation temperature (Pratiwi, 2012). Therefore, in this experiment, we detect the effectiveness of autoinduction method by comparing the amount of fusion protein from the soluble and insoluble fraction. The soluble fraction was extracted by centrifugating the lysed cells, while the insoluble fraction was prepared from residual cells pellet. To evaluate the amount of soluble and insoluble fusion protein, the thickness of target protein bands were semiquantitatively measured using ImageJ software and figured as area under curve (AUC) (Figure 3). The fusion protein was expressed approximately $49 \%$ in soluble fraction and $51 \%$ in insoluble fraction. Consequently, the autoinduction condition still needs to be thoroughly optimized particularly for hG-CSFTrx $\cdot$ tag production. This method depends on the oxygenation state of the culture, the composition of the autoinduction medium, and time - temperature of incubation (Blommel, 2007; Studier, 2005). Tyler (2005) found that $0.6 \%$ or more of glycerol is important to get higher yield.

\section{Purification and characterization hG-CSF}

Some downstream steps were required to gain the hG-CSF e.g., the first purification step to remove E.coli endogenous proteins from fusion protein, and the cleavage of the fusion protein, followed by the second purification step to divide hG-CSF and $6 \times$ His- $^{-}$ Trx tag. The purification was conducted through IMAC (Ni-NTA), a method which is widely used to purify the active and soluble recombinant protein based on the covalent binding of target protein-His $\cdot$ tag towards $\mathrm{Ni}^{2+}$ matrix (Bartlow, 2011, Awade, 1996). In order to recover the target protein, $\mathrm{pH}$ gradient or imidazole is typically used to release the protein target from the matrix (Porath, 1992).

To mitigate endogenous protein contaminants, washing steps were performed in elevated imidazole concentrations prior to elute the fusion protein with an optimized imidazole concentration. The purified fusion protein was acquired from the first to the third elution fractions (Figure 4).

The protein quantification was generated using Image software by calculating the AUC of the protein from Figure 4. The crude protein contained of $10.46 \%$ fusion protein. The purification recovery was $83.56 \%$, by comparing the total AUC of elution fractions towards the AUC of fusion protein from the crude protein, or $8.74 \%$ towards the overall crude protein.

Each $6 \times$ His-Trx $\cdot \operatorname{tag}$ and hG-CSF were separated by EK, a serine protease that recognizes the amino sequence -Asp-Asp-AspAsp-Lys |X-with high specificity (Hopp, 1988). As a preliminary study, $1 \mathrm{U}$ of EK was added to $100 \mu \mathrm{g}$ fusion protein, then it was incubated at $4^{\circ} \mathrm{C}$ and $20^{\circ} \mathrm{C}$ for 16 hours. The fusion protein was succesfully cleaved at both of those temperatures, but not completed yet (Figure 5), thus the ratio of fusion protein and enterokinase has to be optimized.

According to the amount of uncut protein, the cleavage at $4^{\circ} \mathrm{C}$ was more effective than it was at $16^{\circ} \mathrm{C}$. Besides, the degraded proteins which are less than $15 \mathrm{kDa}$ were intensively found after incubation at $16^{\circ} \mathrm{C}$. By using ImageJ software, the effciency of cleavage at $4^{\circ} \mathrm{C}$ was calculated. The AUC of each $\mathrm{hG}$ CSF, Trx, and uncut protein were compared to the AUC of purified fusion protein. The cleavage efficiency was obtained as $21.72 \%$ for hG-CSF and $39.31 \%$ for Trx. On the other hand, $38.05 \%$ protein was unsuccesfully cleaved. 
The cleaved protein was subsequently purified using IMAC by trapping $6 \times$ HisTrx tag on the $\mathrm{Ni}^{2+}$ matrix. The hG-CSF was eluted in flow through fraction. At this step, flow through fraction and elution fraction were still recovered as mixture of $6 \times \mathrm{His}-\mathrm{Trx} \cdot \mathrm{tag}$ and hG-CSF (Figure 6.A). The larger scale experiment with enhanced binding process of protein - matrix is needed. In order to confirm whether the elution fraction possess $6 \times$ HisTrx tag, it was detected by western blot with anti-His primary antibody (Figure 6.B).

\section{CONCLUSION}

Human granulocyte colony stimulating factor has been successfully expressed in fusion with thioredoxin in E.coli BL21(DE3) through autoinduction method. A number of $49 \%$ of this protein was found as soluble fraction, whereas the other $51 \%$ was still found aggregated as IBs. It was succesfully purified using IMAC, cleaved from the fusion Trx partner and confirmed by western blot.

\section{ACKNOWLEDGEMENT}

This research was supported by Indonesian Institute of Sciences (LIPI) Competitive Research Program, under the Post Genomic Molecular Farming Sub-Program.

\section{REFERENCES}

Awade AC., 1996, On hen egg fractionation : applications of liquid chromatography to the isolation and the purification of hen egg white and egg yolk proteins, $Z$ Lebensm unters forsch, $202: 1-14$

Bartlow P., Uechi GT., Cardamone Jr JJ., Sultana T., Fruchtl M., Beitle RR., Ataai MM., 2011, Identification of native Escherichia coli BL21(DE3) proteins that bind to immobilized metal affinity chromatography under high imidazole conditions and use of 2D-DIGE to evaluate contaminations pools with respect to recombinant protein expression level, Prot Expres Purif, 78 : 216-224

Blommel PG., Becker KJ., Duvnjak, P., Fox BG, 2007, Enhanced bacterial protein expression during auto-induction obtained by alteration of lac repressor dosage and medium composition, Biotechnol. Prog., 23, 585 - 598

Dale DC., 1998, The Discovery, Development and Clinical Applications of Granulocyte Colony Stimulating Factor, Trans Am Clin Climatol Assoc, 109 : 27-38

Das KMP., Banerjee S., Shekkar N., Damodaran K., Nair, R., Somani S., et al 2011, Cloning, soluble expression and purification of high yield recombinant hGMCSF in Escherichia coli, Int J Mol Sci, 12, 2064-2076

Dasari VKR., Are D., Joginapally VR., Mangamoori LN., Adibhatla KSBR., 2008, Optimization of the downstream process for high recovery of rhG-CSF, Process Biochem, 43 : 566-575

Deghani SA., Babeipour V., Mofid MR., Faraji F., 2010, An Efficient Prification Method for High Recovery of Recombinant Human Granulocyte Colony Stimulating Factor from Recombinant E.coli, Intl J. Env Sci Dev, 1 (2) : 111-114

Hill CP., Osslund TD., Eisenberg D., 1993, The structure of granulocyte colonystimulating factor and its relationship to other growth factor, Prod Natl Acad Sci USA, 90: 5167--5171

Hopp TP., Prickett KS., Price VL., Libby RT., March CJ., Cerretti DP., Urdal DL., Conloon PJ., 1988, A Short Polypeptide Marker Sequence Useful for Recombinant Protein Identification and Purificaation, Nat Biotechnol, 6 : 1204 1210

Kang YS., Song JA., Han KY., Lee J., 2014, Escherichia coli EDA is a novel fusion expression partner to improve solubility of aggregation-prone heterologous proteins, J Biotechnol, http://dx.doi.org/ 10.1016/j.jbiotec.2014.11.05

LaValielli ER., Diblasio EA., Kovacic S., Grant, KL., Schendel PF., McCoy M., 1993, A Thioredoxin Gene Fusion Expression System That Circumvents Inclusion Body Formation in the E.coli Cytoplasm, Nat Biotechnol, 10 : 187-193

Li Z., Kessler W., van den Heuvel J., Rinas U., 2011, Simple defined autoinduction medium for high-level recombinant 
protein production using T7-based Escherichia coli expression systems. Appl Microbiol Biotechnol, 91 : 1203-1213

Metcalf D., 1987, The Role of The ColonyStimulating Factors in Resistance to Acute Infections, Immunol Cell Biol, 65 : 35-45

Nagata 1986, The chromosomal gene structure and two mRNAs for human granulocyte colony-stimulating factor, The EMBO Journal, 5(3) : 575-581

Porath J., 1992, A review - immobilized metal ion affinity chromatography, Prot Expres Purif, 3 : 263-281

Pratiwi R.D., Fuad AM., 2012, Influence of temperature on recombinant granulocyte colony stimulating factor production by Escherichia coli BL21(DE3) expression system using autoinduction, in Proceedings- International Conference on Biotechnology 2012, ed. Prasetyoputri, A., et al, Research Center for Biotechnology, Indonesian Institute of Sciences, Bogor, Indonesia, pp. 419-427

Sambrook J., Russell DW., 2001, The Inoue Method for Preparation and Transformation of Competent E. coli: "Ultra Competent" Cells,. In Molecular Cloning: A Laboratory Manual, 3rd ed. Cold Spring Harbor, New York. ,p. 116-118

Sandhev D., Chrigwin, J.M., 1998, Solubility of Protein Isolated from Inclusion Bodies Is Enhanced by Fusion to MaltoseBinding Protein or Thioredoxin, Prot Express Purif, 12 : 122-132

Song JA., Lee DS., Park JS., Han KY., Lee J., 2011, A novel Escherichia coli solubility enhancer protein for fusion expression of aggregation-prone heterologous proteins, Ensyme Microbiol Technol, 49, 124-130

Souza LM., Boone TC., Gabrilove J., Lai PH., Zsebo KM., et al., 1986, Recombinant human granulocyte colony-stimulating factor : effect on normal and leukemic myeloid cells, Science, Vol. 232 no.4746 : 61-65

Studier, 2005, Protein production by autoinduction in high density shaking cultures, Protein Expres Purif, 41 : 207-234

Thatcher DR., 1990, Recovery of Theurapetic Proteins from Inclusion Bodies : Problems and Process Strategies, Biochem Soc Trans, 18(2) : 234-235

Tyler RC., Sreenath HK., Singh S., Aceti DJ., Bingman CA., Markley JL., Fox BG., 2005, Auto-induction medium for the production of $[\mathrm{U}-15 \mathrm{~N}]$-and $[\mathrm{U}-13 \mathrm{C}, \mathrm{U}-$ $15 \mathrm{~N}]$-labeled proteins for NMR screening and structure determination, Protein Expr Purif, 40, 268-278

Welte K., 2012, Discovery of G-CSF and early clinical studies, in Twenty Years of G-CSF, Milestone in Drug Therapy, edited by G. Molineux, et al, DOI 10.1007/978-30348-0218-5_2

Wingfield P., Benedict R., Turcatti G., Allet B., Mermod JJ., et al., 1988, Characterization of Recombinant Derived Granulocytecolony stimulating factor (G-CSF), Biochem. J., 256 : 213-218

Wulandari S., 2010, Subkloning Gen Sintetik CSF3syn (Colony Stimulating Factor-3) pada Vektor Ekspresi pET32a(+) dan Transformasi Vektor Rekombinan pada Escherichia coli BL21(DE3)pLysS, Skripsi, Universitas Indonesia, Indonesia

Yamamoto A., Iwata, A., Saitoh T., Tuchiya K., Kanai T., Tsujimoto H., Hasegawa A., Ishihama A., Ueda S., 2002, Expression in Escherichia coli and purification of the functional feline granulocyte colonystimulating factor, Vet Immunol Immunop, $90: 169-177$

Yasukawa T., Ishii CK., Maekawa, T., Fujimoto J., Yamamoto T., Ishii S., 1995, Increase of Solubility of Foreign Proteins in Escherichia coli by Coproduction of the Bacterial Thioredoxin, J Biol Chem, 43 : 25328-25331 